\title{
Medical Image of the Week: Leukemic Infiltrates
}

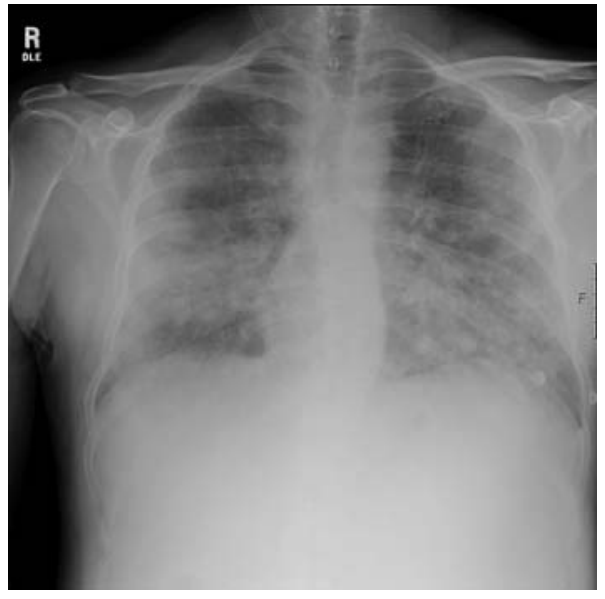

Figure 1. AP portable chest x-ray demonstrating diffuse bilateral infiltrates.

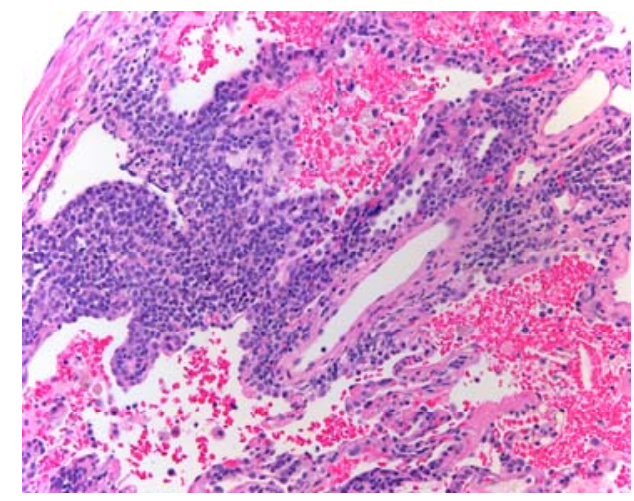

Figure 2. Histology showing extensive interstitial and perivascular lymphocytic infiltrates.

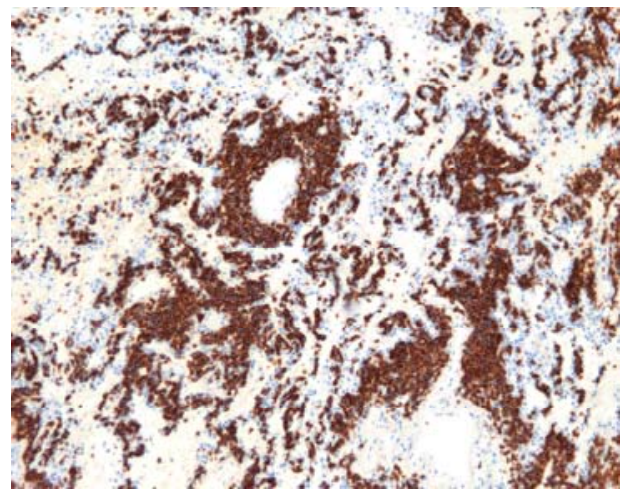

Figure 3. Immunohistochemical staining for CD8 positive T-cell immunophenotype. 
A 50 year-old white man with newly diagnosed, acute T-cell prolymphocytic leukemia presented with progressive exertional dyspnea and non-productive cough. The patient was due to meet with his hematologist that day to discuss initiation of treatment. The patient had not noted fever, chills, night sweats, chest pain, or lower extremity swelling. Blood pressure was $112 / 60 \mathrm{~mm} \mathrm{Hg}$, respiratory rate was $36 /$ minute and labored, pulse was 110/minute and temperature was 37 degrees Celsius. Oxygen saturation measured by pulse oximetry was $62 \%$ on room air at rest, and rose to $90 \%$ after the application of a 100\% non-rebreather mask. Diffuse rales were present on chest auscultation. Marked splenomegaly was present on abdominal examination. Peripheral white blood count was $112.2 \mathrm{~K} / \mathrm{ul}$ with $99 \%$ lymphocytes. Smudge cells were noted. Hemoglobin was 12.9 $\mathrm{g} / \mathrm{dl}$ and platelet count was $93 \mathrm{~K} / \mathrm{ul}$. Procalcitonin level was $0.3 \mathrm{pg} / \mathrm{ml}$. The chest radiograph demonstrated diffuse bilateral infiltrates (Figure 1). The patient developed rapidly progressive hypoxemia, was intubated orally, and mechanical ventilation was initiated. Lung biopsies were performed via a video-assisted thoracic surgical approach of the right middle and right lower lobes. Microscopic examination demonstrated extensive leukemic infiltration of the pulmonary interstitium and perivascular space (Figure 2). Immunohistochemical staining showed that the infiltrating cells expressed a CD8 positive T-cell immunophenotype (Figure 3) pattern similar to the patient's peripheral blood flow cytometry study. Therapy began with an escalating dose of alemtuzumab and intermittent pentostatin, but the patient developed progressive multiorgan failure and expired.

Acute T-cell prolymphocytic leukemia is an aggressive mature T-cell leukemia usually characterized by peripheral blood lymphocytosis and splenomegaly (1). Extramedullary involvement most commonly affects the skin (2). Diffuse interstitial and perivascular pulmonary involvement with respiratory failure has not been previously reported. Pathological involvement of the pulmonary interstitial space should be considered in patients with acute T-cell prolymphocytic leukemia and respiratory insufficiency.

Charles J. VanHook ${ }^{1}$, Carlyne Cool ${ }^{2}$, Todd DeBoom ${ }^{3}$, Robert Fisher ${ }^{4}$, and Douglas J. Tangel ${ }^{1}$

${ }^{1}$ Department of Intensive Care Medicine

Longmont United Hospital

Longmont, $\mathrm{CO}$

${ }^{2}$ Department of Pathology and Department of Medicine

University of Colorado and National Jewish Health

Denver, CO

${ }^{3}$ Department of Pathology

Longmont United Hospital

Longmont, $\mathrm{CO}$

${ }^{4}$ Department of Oncology

Longmont United Hospital

Longmont, $\mathrm{CO}$ 


\section{References}

1. Dearden CE. T-cell prolymphocytic leukemia. Med Oncol. 2006;23(1):17-22. [CrossRef] [PubMed]

2. Valbuena JR, Herling M, Admirand JH, Padula A, Jones D, Medeiros LJ. T-cell prolymphocytic leukemia involving extramedullary sites. Am J Clin Pathol. 2005;123(3):456-64. [CrossRef] [PubMed] 